\title{
Editorial for Special Issue: Achilles Curse and Remedy: Tendon Diseases from Pathophysiology to Novel Therapeutic Approaches
}

\author{
Denitsa Docheva \\ Experimental Trauma Surgery, Department of Trauma Surgery, University Medical Center Regensburg, \\ Am Biopark 9, 93053 Regensburg, Germany; denitsa.docheva@ukr.de; Tel.: +49-941-943-1605
}

Received: 7 October 2020; Accepted: 8 October 2020; Published: 9 October 2020

In Greek mythology, Achilles, the Greek hero, is almost invulnerable-except for his Achilles heel, whose injury resulted in his death. How could a tendon injury take such a prominent place in Greek mythology? This injury was obviously such a crucial and inexplicable event that it was extensively honored in the legendary Iliad of Homer. Presumably, the ancient Greeks had already asked themselves how it could have happened that the greatest tendon of man could suddenly break, even in a young, vigorous athlete.

Tendons are dense connective tissues and critical components for the integrity and function of the musculoskeletal system, as they connect bone to muscle and transmit forces on which locomotion entirely depends. Due to the increasing age of our society and a rise in the engagement of young people in overuse activities or extreme sports, tendon diseases present major clinical and financial challenges in modern medicine. Inevitably, tendinopathies lead to the final stage disease that is tendon rupture, and once this happens, tendon natural healing is slow, often poorly responding to treatments and requiring prolonged rehabilitation in most cases. A major cause of tendon rupture is tendon tissue degeneration, a process that can be considered a failure of matrix adaptation and remodeling because of an imbalance between matrix synthesis and break down due to a variety of stresses and mechanical loads.

There are three main hypotheses about the cause(s) of tendon degeneration: (1) mechanical overuse (via matrix), (2) neo-vascularization (via exogenous cells), and (3) cell and tissue aging (via endogenous cells). Most likely, these three all trigger cross-talk and cross-react with one another, ultimately leading to the failure of the whole tendon unit. To date, there have been only a few approved treatments for tendinopathy that are targeted against specific molecular processes, and still, in most cases, there is little to no evidence of therapeutic effectiveness, especially in the long term. Concerning the therapy of the end-stage disease that is tendon rupture, there are two main clinical algorithms, namely, subjecting patients to surgical or conservative therapy, and both require months-long periods to achieve mostly partial and rarely full structural and functional tendon reconstitution.

This Special Issue aimed to embrace research and review articles concentrating on:

1. The spectrum of tendon pathologies: e.g., triggers, trails, and end-state of tendinopathy by Steinmann et al. [1].

2. Endogenous tendon cells and their governing molecular pathways: e.g., cell-extracellular matrix (ECM) contacts mediated via $\alpha 2 \beta 1$ integrin by Kronenberg et al. [2]; transforming growth factor beta-activated kinase-1 (TAK 1) signaling in tendon and enthesis by Friese et al. [3]; and transcriptional activity of the early growth response 1 (EGR1) gene in healthy and scarred tendons by Havis et al. [4].

3. Cross-talk with exogenous cells: e.g., with macrophages during inflammation by Vinhas et al. [5] and myoblasts at the site of myotendinous junction by Strenzke et al. [6]. 
4. Niche chemical composition: e.g., uremic toxins and antibiotics in pathological kidney conditions by Popowski et al. [7]; tissue chemical changes during tendon aging by Yin et al. [8]; and cartilage oligomeric matrix protein (COMP) fragmentation in tendon injury by Smith et al. [9].

5. Tendon structural composition and biomechanical properties: e.g., alterations in elastic properties after tendon injury by Frankewycz et al. [10] and in vitro and in vivo response of tenocytes to mechanical stimulation by Fleischhacker et al. [11].

6. Medicinal and tissue engineering therapeutic approaches: e.g., pulsed electromagnetic field (PEMF)-based therapy by Vinhas et al. [5]; various percutaneous treatments by Darrieutort-Laffite et al. [12]; enthesial regenerative approaches by Friese et al. [3]; and current tendinopathy management strategies by Steinmann et al. [1].

A total of eight original articles and four review articles are published, as summarized in Table 1.

Table 1. Summary of the articles published in the Special Issue [1-12].

\begin{tabular}{|c|c|c|}
\hline Article Type & Authors & Main Message \\
\hline \multirow{12}{*}{ Original Research Articles } & \multirow[t]{2}{*}{$\begin{array}{c}\text { Adriana Vinhas, Ana F. Almeida, Ana I. } \\
\text { Gonçalves, Márcia T. Rodrigues, and } \\
\text { Manuela E. Gomes [5] }\end{array}$} & $\begin{array}{l}\text { Cross-talk between macrophages and human tendon-derived } \\
\text { cells (hTDCs), using co-culture model with and without IL-1 } \beta \\
\text { stimulation, was investigated. Furthermore, the potential } \\
\text { modulatory effect of pulsed electromagnetic fields (PEMFs) was } \\
\text { examined. The PEMFs influenced a macrophage pro-regenerative } \\
\text { and anti-inflammatory phenotype, and overcame the effect of } \\
\text { IL-1 } \beta \text {-treated hTDCs, thus suggesting a beneficial role of the } \\
\text { PEMF in guiding inflammatory responses toward } \\
\text { tissue regeneration. }\end{array}$ \\
\hline & & In vitro studies \\
\hline & \multirow[t]{2}{*}{$\begin{array}{l}\text { Erman Popowski, Benjamin Kohl, } \\
\text { Tobias Schneider, Joachim Jankowski, } \\
\text { and Gundula Schulze-Tanzil [7] }\end{array}$} & $\begin{array}{l}\text { The effects of the uremic toxins phenylacetic acid (PAA) and } \\
\text { quinolinic acid (QA), both alone and in combination with } \\
\text { ciprofloxacin (CPX), on human tenocytes were studied. CPX, } \\
\text { administered at a therapeutic concentration, suppressed tenocyte } \\
\text { metabolism. Combinations of CPX with PAA or QA did not } \\
\text { cause greater cytotoxicity than incubation with CPX alone. Gene } \\
\text { expression of matrix metalloproteinase } M M P-1 \text { was increased, } \\
\text { while the pro-inflammatory cytokine } I L-1 \beta \text { was reduced by CPX, } \\
\text { but up-regulated by PAA and QA. Type I collagen protein } \\
\text { decreased only in response to high CPX doses, demonstrating } \\
\text { that CPX was more tenotoxic than the uremic toxins. }\end{array}$ \\
\hline & & In vitro studies \\
\hline & \multirow[t]{2}{*}{$\begin{array}{c}\text { Borys Frankewycz, Leopold Henssler, } \\
\text { Johannes Weber, Natascha Platz Batista } \\
\text { da Silva, Matthias Koch, Ernst Michael } \\
\text { Jung, Denitsa Docheva, Volker Alt, and } \\
\text { Christian G. Pfeifer [10] }\end{array}$} & $\begin{array}{l}\text { Using shear wave elastography technology, } 12 \text { patients who } \\
\text { suffered from an acute Achilles tendon rupture were acquired } \\
\text { and monitored for one year, revealing a significant increase in } \\
\text { tendon scar elastic properties within the first six weeks and a } \\
\text { second significant increase three to six months after injury. This } \\
\text { pilot study suggested a time correlation of biomechanical } \\
\text { properties with the biological healing phases of tendon tissue, } \\
\text { which could be implemented in treatment and aftercare protocols. }\end{array}$ \\
\hline & & Patient study \\
\hline & \multirow[t]{2}{*}{$\begin{array}{l}\text { Daniel Kronenberg, Philipp A. Michel, } \\
\text { Eva Hochstrat, Ma Wei, Jürgen } \\
\text { Brinckmann, Marcus Müller, Andre } \\
\text { Frank, Uwe Hansen, Beate Eckes and } \\
\text { Richard Stange [2] }\end{array}$} & $\begin{array}{l}\text { Tendon tissue and cells from wild-type and integrin } \alpha 2 \beta 1 \\
\text { knockout mice were compared. Significantly smaller collagen } \\
\text { fibrils, altered dynamic E-modulus, increased C-terminal } \\
\text { fragments of type I collagen, and MMP- } 2 \text { activity were detected } \\
\text { in } \alpha 2 \beta 1 \text {-deficient tendons. Moreover, the mutant tenocytes } \\
\text { produced more collagen in vitro. These results report a } \\
\text { significant role of } \alpha 2 \beta 1 \text { in tendon tissue and a potential link to } \\
\text { chronic tendinosis. }\end{array}$ \\
\hline & & In vivo and in vitro studies \\
\hline & \multirow[t]{2}{*}{$\begin{array}{c}\text { Roger Smith, Patrik Önnerfjord, Kristin } \\
\text { Holmgren, Shacko di Grado, and Jayesh } \\
\text { Dudhia [9] }\end{array}$} & $\begin{array}{l}\text { Cartilage oligomeric matrix protein (COMP) fragments were } \\
\text { purified from synovial fluids of horses with intra-thecal tendon } \\
\text { injuries and media from equine tendon explants, and analyzed by } \\
\text { mass spectrometry and competitive inhibition ELISA, revealing a } \\
\text { significant increase in the COMP neo-epitope with tendon injury, } \\
\text { suggesting that this assay could be suitable for clinical use. }\end{array}$ \\
\hline & & In vivo and in vitro studies \\
\hline & \multirow[t]{2}{*}{$\begin{array}{l}\text { Nai-Hao Yin, Anthony W. Parker, Pavel } \\
\text { Matousek, and Helen L. Birch [8] }\end{array}$} & $\begin{array}{l}\text { In order to gain better understanding of the chemical differences } \\
\text { between young and old tendons, fluorescence and Raman } \\
\text { combined spectra analyses were carried out with vacuum-dried } \\
\text { young and old equine superficial digital flexor and deep digital } \\
\text { flexor tendons. The analysis indicated increased fluorescence, } \\
\text { changes in intra-tendinous fluorophores, a decline in cellular } \\
\text { numbers, and an accumulation of advanced glycation end } \\
\text { products as tendons aged, signifying that Raman spectroscopy } \\
\text { can successfully detect age-related tendon molecular differences. }\end{array}$ \\
\hline & & In vivo studies \\
\hline
\end{tabular}


Table 1. Cont.

\begin{tabular}{|c|c|c|}
\hline Article Type & Authors & Main Message \\
\hline & $\begin{array}{l}\text { Maximilian Strenzke, Paolo Alberton, } \\
\text { Attila Aszodi, Denitsa Docheva, } \\
\text { Elisabeth Haas, Christian } \\
\text { Kammerlander, Wolfgang Böcker, and } \\
\text { Maximilian Michael Saller [6] }\end{array}$ & $\begin{array}{l}\text { To investigate new mechanisms in musculotendinous interaction, } \\
\text { myoblasts were exposed to a secretome obtained from a } \\
\text { Scleraxis-overexpressing mesenchymal stem cell (MSC) line, } \\
\text { which led to a significant increase in myoblast fusion and } \\
\text { metabolic activity, but had no effect on myoblast migration and } \\
\text { myofiber alignment. RNA sequencing revealed differential } \\
\text { expression of genes encoding ECM proteins, transmembrane } \\
\text { receptors and proteases between native MSCs and Scleraxis MSCs. }\end{array}$ \\
\hline & & In vitro studies \\
\hline & $\begin{array}{l}\text { Viviane Fleischhacker, Franka } \\
\text { Klatte-Schulz, Susann Minkwitz, Aysha } \\
\text { Schmock, Maximilian Rummler, Anne } \\
\text { Seliger, Bettina M. Willie, and Britt } \\
\text { Wildemann [11] }\end{array}$ & $\begin{array}{l}\text { Comparative analysis of in vitro and in vivo cyclic compressive } \\
\text { loading of Achilles tendon-derived tenocytes revealed similar } \\
\text { expression profiles of tendon-associated gene markers, but } \\
\text { interestingly, significant differences in cell shape and gene } \\
\text { expression levels of collagen I, collagen III, and MMPs. These data } \\
\text { can help in understanding how closely in vitro stimulation of } \\
\text { tenocytes mimics the in vivo situation. }\end{array}$ \\
\hline & & In vivo and in vitro studies \\
\hline \multirow{4}{*}{ Review Articles } & $\begin{array}{l}\text { Christelle Darrieutort-Laffite, Louis J. } \\
\text { Soslowsky, and Benoit Le Goff [12] }\end{array}$ & $\begin{array}{l}\text { Various percutaneous treatments have been applied to tendon } \\
\text { lesions: e.g., injectable treatments, platelet-rich plasma, } \\
\text { corticosteroids, stem cells, MMP inhibitors, and anti-angiogenic } \\
\text { agents. This review summarized the molecular and structural } \\
\text { effects of such treatments obtained in vitro and in vivo, as well as } \\
\text { their efficacy in clinical trials, and concluded that local treatments } \\
\text { had some impact on neovascularization, inflammation, or tissue } \\
\text { remodeling in animal models, but clinical evidence remained too } \\
\text { weak, therefore, further studies are needed to evaluate their value. }\end{array}$ \\
\hline & $\begin{array}{l}\text { Nina Friese, Mattis Benno Gierschner, } \\
\text { Patrik Schadzek, Yvonne Roger, and } \\
\text { Andrea Hoffmann [3] }\end{array}$ & $\begin{array}{l}\text { This review focused on the transition zone from bone to } \\
\text { tendon-the enthesis, its anatomical structure, development } \\
\text { during embryogenesis, and dysfunction during inflammation, } \\
\text { with particular attention on the role of a signaling mediator } \\
\text { protein, transforming growth factor beta-activated kinase- } 1 \\
\text { (TAK1). Furthermore, a short synopsis on the current progress in } \\
\text { restorative strategies for damaged enthesis was given. }\end{array}$ \\
\hline & $\begin{array}{c}\text { Emmanuelle Havis and Delphine } \\
\text { Duprez [4] }\end{array}$ & $\begin{array}{l}\text { This review provided a broad overview on the roles of the early } \\
\text { growth response } 1 \text { (EGR1) gene in tendon, cartilage, bone, and } \\
\text { adipose tissues, as well as on EGR1 involvement in tissue and } \\
\text { organ fibrosis and on the link between its transcriptional activity } \\
\text { and abnormal ECM production, suggesting EGR1 as a potential } \\
\text { therapeutic target to fight fibrotic conditions or to modulate } \\
\text { tendon repair. }\end{array}$ \\
\hline & $\begin{array}{c}\text { Sara Steinmann, Christian G. Pfeifer, } \\
\text { Christoph Brochhausen, and Denitsa } \\
\text { Docheva [1] }\end{array}$ & $\begin{array}{l}\text { This review encompassed detailed information on morbidity and } \\
\text { clinical relevance of tendinopathies; histopathological, structural, } \\
\text { cellular, epigenetic, transcriptomic, proteomic, and metabolomic } \\
\text { changes during tendinopathy; involvement of vasculature, } \\
\text { inflammation, and neurons; and biochemical and biomechanical } \\
\text { alterations, as well as on the current tendinopathy management } \\
\text { strategies. A graphical summary on the current knowledge of } \\
\text { triggers, trails, and the end state of tendinopathies was provided. } \\
\text { The review anticipated a more systematic and multidisciplinary } \\
\text { approach to decipher the complexity behind tendinopathy and to } \\
\text { outline possible ways forward to combat tendinopathy. }\end{array}$ \\
\hline
\end{tabular}

Funding: This research received no external funding.

Acknowledgments: Denitsa Docheva acknowledges the financial support of the EU H2020-WIDESPREAD-05 -2017-Twinning Grant "Achilles: Overcoming specific weakness in tendon biology to design advanced regenerative therapies" Proposal Nr. 810850 and the consortium partners Manuela E. Gomes, Dimitrios Zeugolis and Christopher H. Evans for collaboration.

Conflicts of Interest: The author declares no conflict of interest. 


\section{References}

1. Steinmann, S.; Pfeifer, C.G.; Brochhausen, C.; Docheva, D. Spectrum of Tendon Pathologies: Triggers, Trails and End-State. Int. J. Mol. Sci. 2020, 21, 844. [CrossRef] [PubMed]

2. Kronenberg, D.; Michel, P.A.; Hochstrat, A.; Wei, M.; Brinckmann, J.; Müller, M.; Frank, A.; Hansen, U.; Eckes, B.; Stange, R. Increased Collagen Turnover Impairs Tendon Microstructure and Stability in Integrin

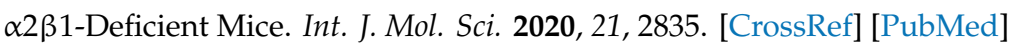

3. Friese, N.; Gierschner, M.B.; Schadzek, P.; Roger, Y.; Hoffmann, A. Regeneration of Damaged Tendon-Bone Junctions (Entheses)_TAK1 as a Potential Node Factor. Int. J. Mol. Sci. 2020, 21, 5177. [CrossRef] [PubMed]

4. Havis, E.; Duprez, D. EGR1 Transcription Factor is a Multifaceted Regulator of Matrix Production in Tendons and Other Connective Tissues. Int. J. Mol. Sci. 2020, 21, 1664. [CrossRef] [PubMed]

5. Vinhas, A.; Almeida, A.F.; Gonçalves, A.I.; Rodrigues, M.T.; Gomes, M.E. Magnetic Stimulation Drives Macrophage Polarization in Cell to-Cell Communication with IL-1 $\beta$ Primed Tendon Cells. Int. J. Mol. Sci. 2020, 21, 5441. [CrossRef] [PubMed]

6. Strenzke, M.; Alberton, P.; Aszodi, A.; Docheva, D.; Haas, E.; Kammerlander, C.; Böcker, W.; Saller, M.M. Tenogenic Contribution to Skeletal Muscle Regeneration: The Secretome of Scleraxis Overexpressing Mesenchymal Stem Cells Enhances Myogenic Differentiation In Vitro. Int. J. Mol. Sci. 2020, $21,1965$. [CrossRef] [PubMed]

7. Popowski, E.; Kohl, B.; Schneider, T.; Jankowski, J.; Schulze-Tanzil, G. Uremic Toxins and Ciprofloxacin Affect Human Tenocytes In Vitro. Int. J. Mol. Sci. 2020, 21, 4241. [CrossRef] [PubMed]

8. Yin, N.; Parker, A.W.; Matousek, P.; Birch, H.L. Detection of Age-Related Changes in Tendon Molecular Composition by Raman Spectroscopy-Potential for Rapid, Non-Invasive Assessment of Susceptibility to Injury. Int. J. Mol. Sci. 2020, 21, 2150. [CrossRef] [PubMed]

9. Smith, R.; Önnerfjord, P.; Holmgren, K.; di Grado, S.; Dudhia, J. Development of a Cartilage Oligomeric Matrix Protein Neo-Epitope Assay for the Detection of Intra-Thecal Tendon Disease. Int. J. Mol. Sci. 2020, 21, 2155. [CrossRef] [PubMed]

10. Frankewycz, B.; Henssler, L.; Weber, J.; Platz Batista da Silva, N.; Koch, M.; Jung, E.M.; Docheva, D.; Alt, V.; Pfeifer, C.G. Changes of Material Elastic Properties during Healing of Ruptured Achilles Tendons Measured with Shear Wave Elastography: A Pilot Study. Int. J. Mol. Sci. 2020, 21, 3427. [CrossRef] [PubMed]

11. Fleischhacker, V.; Klatte-Schulz, F.; Minkwitz, S.; Schmock, A.; Rummler, M.; Seliger, A.; Willie, B.M.; Wildemann, B. In Vivo and In Vitro Mechanical Loading of Mouse Achilles Tendons and Tenocytes-A Pilot Study. Int. J. Mol. Sci. 2020, 21, 1313. [CrossRef] [PubMed]

12. Darrieutort-Laffite, C.; Soslowsky, L.J.; Le Goff, B. Molecular and Structural Effects of Percutaneous Interventions in Chronic Achilles Tendinopathy. Int. J. Mol. Sci. 2020, 21, 7000. [CrossRef] [PubMed] 